\title{
Personality Type, Organizational Commitment and Collaborative alliance among University of Perpetual Help System Laguna (UPHSL) Academic Personnel
}

\author{
Sherill S. Villaluz \\ Faculty, College of Arts and Sciences \\ Leomar S. Galicia \\ Research Director \\ University of Perpetual Help System Laguna \\ Sto. Nino, Binan, Laguna, Philippines
}

\begin{abstract}
Higher education accommodated different partnership, alliances and collaboration which serve as mechanism for delivering quality education. The academic personnel of UPHSL are encouraged to participate in support services. Also, it is imperative that collaboration among employees are evident. This study identified how thepersonality type of the 43 academic personnel relates to their organizational commitment and how such relate to their collaborative alliance.This descriptive-correlation research used convenience sampling. Findings showed that the more the respondents manifest abasement, achievement, deference, and respect for others, the higher is their level of organizational commitment; the more theymanifest such traits, the greater is their extent of collaborative alliance in terms of giving quality service to satisfy their stakeholders; the higher the level of the academic personnel's organizational commitment, the greater is their involvement in institutional marketing and promotion, community outreach program involvement and customer satisfaction.
\end{abstract}

Keywords: collaborative alliance, organizational commitment, Perpetualites campus-based personality type

\section{Introduction}

Higher education has irreversibly changed over the past 15-20 years. University education has moved from an elite system to a mass system and that they have accommodated different forms of partnership, alliances and collaboration. (Armstrong,2015) No doubt, cross-sectoral alliances are mechanism for enhancing service delivery in education (Wohlstetter, et.al.2004). Additionally, institutions face pressure from governmental agencies and industry to support collaborativeactivity on campus (Harris, 2010).

The academic personnel of the University of Perpetual Help System (UPHSL) possess stereotypic trait distinct among true Perpetualites, that is, one who has faith in his self, who perceives his natural goodness, one who takes a gander at his confinements and flaws, one lets go of the past and takes control of the present, one who grabs the occasion and one who changes and enables (Medina, Rosas \&Vitug, 2017). Further, a Perpetualite is one who has faith in his self, who perceives his natural goodness, one who takes a gander at his confinements and flaws, one who let go of the past and take control of the present, one who grabs the occasion, and one who is open to change (Perpetualite Community, 2015). According to Pappas (2013), there are numerous methods to determine personality, however some psychology have predominantly given up to divide humanity neatly into types. Because of that, they focus on personality traits.

This study was anchored on the Organizational Commitment Theory of Aaron Cohen (Kessler, 2013) which emphasized that organizational commitment (OC) centers on the employees' sense of attachment and loyalty to the work organization with which the employee is associated. It is defined in terms of an employee's attitudes and intentions (understood as the precursors of behavior). Employees are committed to the organization when their goals are congruent with those of the organization, when they are willing to exert effort on behalf of the organization, and when they desire to maintain their connection with the organization. Unsurprisingly, OC has been shown to be a key antecedent of other important attitudes and behaviors, including those related to performance and turnover. To determine the success of one organization, it is important to consider the amount of commitment employees devote to their organization. As how Quiambao and Nuqui (2017) point it, increased job commitment improves employees job fulfillment, motivation performances and creativeness and reduces inefficiency and dissatisfaction. Organizational commitment highlights the employees' identification and integration level and the feelings of anindividual about an organization and psychological commitment of an individual might includeparticipation the work, loyalty and beliefs to the organization values (Yalcin, 2016). 
Kanter (1968) as cited by Savas, Kosker, Demir andUtar (2015) analyzed commitment under three dimensions including continuance, adaptation and control commitment where continuance commitment is related to employees' cognitive systems. In this type of commitment, when employees consider cost, they realize that the cost of leaving the organization is more than the cost of staying in the organization (Topaloglu, 2010).On the other hand, interlock commitment (adaptation commitment) means that employees desist previous social relationships or involve social relationships through symbols, signs or joining ceremonies in an organization (Gul, 2002) and control commitment describes the process in which employees attach to organizational norms by forming their behaviors at will.

Gruay, et.al (2016) holds that personality traits have direct relationship with organizational commitment yet, organizations face various challenges that might affect organizational commitment (Upchurch,Curtis\& Denver,2009) and the UPHL is not an exemption.It is for this reason that the idea of collaborative alliance between and among different departments have been introduced. According to Oliver (1990) and Roberston (1998), as cited byWohlstetter, Malloy,Hentschke and Smith (2004) organizations oftenrequire additional resources to provide stability as they pursue new ventures. When resources are scarce alliances can serve as an effective coping mechanism through whichto forestall, predict, or absorb uncertainty and achieve a reliable resource flow and exchange. In UPHSL, employees are encouraged to participate in services such as marketing and promotion, research involvement, community outreach program involvement, and customer satisfaction. Marketization of higher education as highlighted in the study of Judson and Taylor (2014) was referred to as the increasing influence of market competition on academic life. Universities often proudly proclaim achievements in student satisfaction across their marketing communications. The recent general movement toward themarketization of university education can be historically traced to political foundations that resulted in an increased emphasis on personalization in pedagogy. But despite the lack of coherent marketing ideology and practice, studies, according to Oplatka (2007)have shown that many managerial as well as organizationalschool activities may be regarded, to a large extent, as part of a marketingpractice It follows thatmany marketing activities, unidentified as such, take place in schools inthe form of open days, day visits, improvement of physical appearance,prospectus formulation, brochures, service development, and public relations.

On the collaborative alliance in terms of research, Huang (n.d.) Higher Education Institutes (HEIs) are giving incentives for their researchers to take part in international collaborative projects.Zarah (2018) emphasized that research collaboration has many known benefits and one of which is that it could be a tool for building knowledge and efficient learning which is an integral role of an educational system. Meanwhile Ekkanath (2017) emphasized that community service is an integral part of educational system and it could be in varied different forms. One can choose community service based on one's skills, schedule, and future career goals. One who is interested in the medical field can look for volunteering opportunities at hospitals, hospices, mental health institutions, or nursing homes. Or if one is fond of physical activity and fitness, he can take part in a charity run, walk, or cleanup drive. Still some might also take up teaching or coaching, so as to impart some knowledge and skills to other people from helping younger kids out with their schoolwork, teaching a sport, or running a craft activity for young children.

The academic personnel of the UPHSL is encouraged to participate in various support services which are essential in ensuring delivery of quality education. Although considerable number of studies were conducted highlighting personality, commitment and collaboration with and among employees, limited studies were conducting linking the three variables. Also, the researcher deemed it imperative that collaboration and cooperation with and among employees are evident thus, the researcher proposed a study on personality type, organizational commitment and collaborative alliance among the academic personnel. The goal of this research is identify theacademic personnel's personality type based from Perpetualites Campus-based Personality Profile by Medina, Rosas \&Vitugin terms of (1) abasement; (2) achievement; (3) deference; (4) modesty; (5) optimism, and (6) respect of others. It also looked into the respondents' level of organizational commitment, their extent of collaborative alliance along institutional (1) marketing and promotion, (2) research involvement, (3) community outreach program involvement, and (4)customer satisfaction. Further, it delved on how the respondents' personality type significantly relate to their level of organizational commitment and to their extent of collaborative alliance, and lastly, how the respondents' level of organizational commitment significantly relates to their extent of collaborative alliance.

\section{Methods}

The respondents of this descriptive-correlational study were 43 out of 62 academic personnel from the college department of the University of Perpetual Help System Laguna representing sixty-nine percent retrieval rate. They consisted of college faculty members and personnel from varied support services such as Community Extension Office, Student Personnel Services, Research and Development Center, Alumni Office, Library and Marketing Department. Total population sampling was used. 
The researcher used a questionnaire for the purpose of collecting the needed data. It was divided into two (3) parts: Part 1 identified the respondents' personality type based from the Perpetualites Personality Measure by Medina, Rosas and Vitug (2017) which focused on six (6) personality traits which are abasement, achievement, deference, modesty, optimism and respect for others. Twenty-five (25) indicators per trait were being presented which yielded .982 Cronbach's Alpha result indicating high reliability result. Part 2 concentrated on the respondents' level of organizational commitment which was adopted from Hayday's Organizational Commitment Inventory (Quiambao \& Nuqui,2017). It comprised of twenty-five (25) items focusing on the respondents' commitment to UPHSL with .912 Cronbach's Alpha result indicating high reliability result.Part 3 measured the respondents' extent of collaborative alliance along four (4) important support services of the UPHSL which are marketing and promotion, research involvement, community outreach program involvement and customer satisfaction which yielded .882 Cronbach's Alpha result indicating high reliability.To ensure validity of the items, the instrument was validated by experts in psychology, research and statistics.

Weighted mean was used to describe the respondents' personality type along abasement, achievement, deference, modesty, optimism and respect for othersand the following measures were used: (5) 4.51-5.00 for most likely of me, (4) 3.51- 4.50 for likely of me, (3) $2.51-3.50$ for less likely of me, (2) 1.51-2.50 for least likely of me and (1) $1.00-1.50$ for not likely of me.For the respondents' level of organizational commitment, still weighted mean was used where (4) 3.51- 4.50 for strongly agree (very high); (3) 2.51 - 3.50 for agree (high); (2) 1.51-2.50 for disagree (low) and (1) 1.001.50 for strongly disagree (very low). Weighted mean was also used to determine the respondents' extent of collaborative alliance along marketing and promotion, research involvement, community outreach program involvement and customer satisfaction where (4) 3.51- 4.50 for or strongly agree (to a great extent), (3) 2.51- 3.50 for agree (to a moderate extent), (2) 1.51-2.50 for disagree (to a less extent) and (1) 1.00- 1.50 for strongly disagree (to a least extent). Pearson $r$ was used to determine how their personality type significantly relate to their level of organizational commitment, how their personality type significantly relate to their extent of collaborative alliance and how their level of organizational commitment significantly relate to their extent of collaborative alliance.

Respondents were being oriented on the nature and depth of the study. After they expressed their consent to participate of the study they were given direction on how to respond to the instrument. They were assured of the confidentiality of their responses.

\section{Results and Discussions}

Table 1. The Academic Personnel's Personality Type: Abasement

\begin{tabular}{|l|c|c|c|}
\hline \multicolumn{1}{|c|}{ Indicators } & $\begin{array}{c}\text { Weighted } \\
\text { Mean }\end{array}$ & $\begin{array}{c}\text { Verbal } \\
\text { Interpretation }\end{array}$ & Rank \\
\hline \multicolumn{1}{|c|}{ I take others' opinions without negative feelings. } & 4.32 & Likely of me & 11 \\
\hline I comply with the decision of others. & 4.09 & Likely of me & 17 \\
\hline I am willing to be apprehended whenever necessary. & 3.79 & Likely of me & 21 \\
\hline I apologize to others whenever necessary. & 4.21 & Likely of me & 13.5 \\
\hline I reached out to the people I had issues with. & 3.60 & Likely of me & 23 \\
\hline I comply to university rules and regulations. & 4.47 & Likely of me & 1.5 \\
\hline I give chance to others. & 4.47 & Likely of me & 1.5 \\
\hline I allow myself to be influenced by others. & 3.00 & Likely of me & 24.5 \\
\hline I agree to someone's ideas and opinions. & 4.17 & Likely of me & 15 \\
\hline I offer the responsibility to others whom I believe can do well. & 4.26 & Likely of me & 8 \\
\hline As a Perpetualite ,I conform to school/organizational policies & 4.38 & Likely of me & 5 \\
\hline I express regret for saying something wrong. & 4.23 & Likely of me & 11 \\
\hline I confess my flaws. & 3.66 & Likely of me & 22 \\
\hline I imitate positive things about others. & 4.15 & Likely of me & 16 \\
\hline I accept my punishments when necessary. & 4.28 & Likely of me & 6.5 \\
\hline I say sorry if I offend someone's feelings. & 4.21 & Likely of me & 13.5 \\
\hline $\begin{array}{l}\text { As a Perpetualite, I apologize if I disobey the rules and regulations } \\
\text { of the university. }\end{array}$ & 4.23 & Likely of me & 11 \\
\hline I accept other people's opinion. & & & \\
\hline I get easily influenced by others. & 3.43 & Likely of me & 4 \\
\hline I surrender to an argument if I know I will not win or succeed. & 3.98 & Likely of me & 24.5 \\
\hline $\begin{array}{l}\text { I get easily influenced by people who have the ability to perform } \\
\text { well. }\end{array}$ & 3.96 & Likely of me & 18 \\
\hline
\end{tabular}




\begin{tabular}{|l|c|l|c|}
\hline I do all the things that I have to do without complaining. & 4.28 & Likely of me & 6.5 \\
\hline I willingly take the consequences for my actions. & 4.45 & Likely of me & 3 \\
\hline I do what I am asked to do. & 4.26 & Likely of me & 9 \\
\hline I refrain from using vulgar or negative language. & 3.91 & Likely of me & 20 \\
\hline Average Weighted Mean & 4.08 & \multicolumn{2}{|c|}{ Likely of me } \\
\hline
\end{tabular}

Generally, the respondents' personality type in terms of abasement obtained an average weighted mean of 4.08 verbally interpreted as "likely of me". This means that the academic personnel likely manifest abasement as a tendency to surrender, to comply and to accept punishment whenever necessary. (Medina, et.al, 2017).

Table 2. The Academic Personnel's Personality Type: Achievement

\begin{tabular}{|l|c|c|c|}
\hline \multicolumn{1}{|c|}{ Indicators } & $\begin{array}{c}\text { Weighted } \\
\text { Mean }\end{array}$ & $\begin{array}{c}\text { Verbal } \\
\text { Interpretation }\end{array}$ & Rank \\
\hline 1. I overcome obstacles. & 4.34 & Likely of me & 14.5 \\
\hline 2. I exercise power. & 3.36 & Less likely of me & 25 \\
\hline 3.I strive to do something difficult. & 4.36 & Likely of me & 11 \\
\hline 4.I strive to do something as quickly as possible. & 4.17 & Likely of me & 22 \\
\hline 5.I accomplished tasks. & 4.51 & Most likely of me & 3.5 \\
\hline 6.I work hard to achieve my goals. & 4.55 & Most likely of me & 2 \\
\hline 7.I aim for goals that motivates me. & 4.40 & Likely of me & 8 \\
\hline 8.I do things successfully. & 4.40 & Likely of me & 8 \\
\hline 9.I do things with much effort. & 4.36 & Likely of me & 11 \\
\hline 10.I do things with courage. & 4.32 & Likely of me & 17 \\
\hline 11.I fulfill my ambitions. & 4.02 & Likely of me & 24 \\
\hline 12.I am positive that I can accomplish my works. & 4.30 & Likely of me & 18 \\
\hline 13. I make things happen like my work plans. & 4.26 & Likely of me & 19 \\
\hline 14.I set goals. & 4.36 & Likely of me & 11 \\
\hline 15.I am willing to take chances. & 4.23 & Likely of me & 20 \\
\hline 16.I focus on my objectives. & 4.40 & Likely of me & 8 \\
\hline 17.I finish my work on time. & 4.43 & Likely of me & 6 \\
\hline 18.I set time for my plans. & 4.34 & Likely of me & 14.5 \\
\hline 19.I aim for success. & 4.51 & Most likely of me & 3.5 \\
\hline 20.I am an ambitious person. & 4.19 & Likely of me & 21 \\
\hline 21.I grab every opportunity. & 4.11 & Likely of me & 23 \\
\hline 22.I conquer the challenges in my life. & 4.34 & Likely of me & 14.5 \\
\hline 23.I visualize what I want. & 4.34 & Likely of me & 14.5 \\
\hline 24.I finish my work/s on time. & 4.60 & Most likely of me & 1 \\
\hline 25. I have goals. & 4.49 & Likely of me & 5 \\
\hline Average Weighted Mean & 4.31 & Likely of me & \\
\hline
\end{tabular}

The average weighted mean of the respondents' personality traits in terms of achievement was 4.31 verbally interpreted as "likely of me". This means that the respondents were likely to overcome obstacles, exercise power and to strive to do something difficult as well as quickly as possible (Medina, et.al, 2017).

Table 3. The Academic Personnel's Personality Type: Deference

\begin{tabular}{|l|c|c|c|}
\hline \multicolumn{1}{|c|}{ Indicators } & $\begin{array}{c}\text { Weighted } \\
\text { Mean }\end{array}$ & $\begin{array}{c}\text { Verbal } \\
\text { Interpretation }\end{array}$ & Rank \\
\hline \multicolumn{1}{|c|}{ I see myself as a good follower. } & 4.15 & Likely of me & 21 \\
\hline I perform my duties in school/organization with willingness. & 4.62 & Most likely of me & 5 \\
\hline I always cooperate with the group leader & 4.64 & Most likely of me & 3.5 \\
\hline I am obedient with my professors/superior. & 4.45 & Likely of me & 10 \\
\hline I respect all the professors/superiors. & 4.74 & Most likely of me & 1 \\
\hline $\begin{array}{l}\text { I congratulate the team leaders/co-employees who did better on } \\
\text { their jobs/tasks. }\end{array}$ & 4.64 & Most likely of me & 3.5 \\
\hline $\begin{array}{l}\text { I consider my professors/boss as my inspiration when it comes } \\
\text { to studying/work performance. }\end{array}$ & 4.34 & Likely of me & 17 \\
\hline I respect other people from other departments. & 4.72 & Most likely of me & 2 \\
\hline
\end{tabular}




\begin{tabular}{|l|c|c|c|}
\hline I trust the plans of the team leader. & 4.28 & Likely of me & 19.5 \\
\hline I am an obedient student/employee. & 4.38 & Likely of me & 14 \\
\hline I do admire my superiors who manifest Perpetualite values. & 4.36 & Likely of me & 15.5 \\
\hline I serve my Perpetual community gladly. & 4.36 & Likely of me & 15.5 \\
\hline I follow the rules given by the team leader/superiors. & 4.49 & Likely of me & 7 \\
\hline I do appreciate the efforts of my team leader/superior. & 4.32 & Likely of me & 18 \\
\hline I can understand the reasons set by authorities. & 4.28 & Likely of me & 19.5 \\
\hline I praise others every time they complete a task. & 4.49 & Likely of me & 7 \\
\hline I admire the positivity of a professor/team leader. & 4.49 & Likely of me & 7 \\
\hline I consider a leader as my partner to be successful. & 4.47 & Likely of me & 9 \\
\hline I help the team leader/superior to improve our team. & 4.40 & Likely of me & 13 \\
\hline I allow others to help me improve myself. & 3.94 & Likely of me & 24 \\
\hline I'm willing to serve for authority. & 4.09 & Likely of me & 22.5 \\
\hline I trust the leader more than anyone else in the group. & 3.81 & Likely of me & 25 \\
\hline I do as I am told. & 4.09 & Likely of me & 22.5 \\
\hline I conduct my duties as told. & 4.43 & Likely of me & 11.5 \\
\hline I accept help from my superiors. & 4.43 & Likely of me & 11.5 \\
\hline Average Weighted Mean & 4.38 & Likely of me \\
\hline
\end{tabular}

The average weighted mean of 4.38 interpreted as "likely of me" mean that the respondents are likely to display the tendency to admire and willingly follow a superior, cooperate with him and to offer extenuations, explanations, and excuses (Medina, et.al, 2017).

Table 4. The Academic Personnel's Personality Type: Modesty

\begin{tabular}{|l|c|c|c|}
\hline \multicolumn{1}{|c|}{ Indicators } & $\begin{array}{c}\text { Weighted } \\
\text { Mean }\end{array}$ & $\begin{array}{c}\text { Verbal } \\
\text { Interpretation }\end{array}$ & Rank \\
\hline \multicolumn{1}{|c|}{ I protect my own privacy when it comes to public. } & 4.53 & Most likely of me & 1 \\
\hline I refuse to participate school/organizational activities. & 2.23 & Not likely of me & 24.5 \\
\hline I avoid any clothing that reveals too much skin. & 4.00 & Likely of me & 13.5 \\
\hline I avoid having issues with my co-Perpetualite. & 4.32 & Likely of me & 7 \\
\hline I refrain asking help from others if I can do it by myself. & 4.40 & Likely of me & 6 \\
\hline I have the habit of excluding myself from others. & 3.13 & Less likely of me & 22 \\
\hline I stay away from crowded places. & 4.13 & Likely of me & 9 \\
\hline I talk with a calm voice. & 3.74 & Likely of me & 20 \\
\hline I keep away from being exposed to public. & 4.00 & Likely of me & 13.5 \\
\hline I avoid socializing with people. & 3.09 & Less likely of me & 23 \\
\hline I refrain to accept offer from someone as long as possible. & 4.09 & Likely of me & 10 \\
\hline I refuse to consider others' opinions. & 2.23 & Not likely of me & 24.5 \\
\hline I usually avoid posting things about myself on social media. & 3.91 & Likely of me & 16.5 \\
\hline I refuse to brag my academic accomplishments and talents. & 3.89 & Likely of me & 18 \\
\hline I prefer to work alone rather than in a group. & 4.02 & Likely of me & 12 \\
\hline I open-up my private life to God instead of talking to others. & 4.43 & Likely of me & 5 \\
\hline $\begin{array}{l}\text { I refuse to show my true emotions because people might } \\
\text { misunderstand me. }\end{array}$ & 3.38 & Less likely of me & 21 \\
\hline It is difficult for me to trust people easily. & & & \\
\hline I prefer to work by myself. & 3.98 & Likely of me & 15 \\
\hline I protect my privacy from others. & 3.91 & Likely of me & 16.5 \\
\hline I resist the urge to brag about myself. & 4.51 & Most likely of me & 3 \\
\hline I enjoy doing things on my own. & 4.06 & Likely of me & 11 \\
\hline I humbly accept compliments from others. & 4.15 & Likely of me & 8 \\
\hline $\begin{array}{l}\text { I have socially accepted behavior which is a signature character } \\
\text { of a true blooded Perpetualite. }\end{array}$ & 4.51 & Most likely of me & 3 \\
\hline I refrain from using vulgar language. & Most likely of me & 3 \\
\hline Average Weighted Mean & 3.81 & Likely of me & 19 \\
\hline
\end{tabular}


The average weighted mean of 3.88 indicated that the respondents reported that the respondents' personality profile in terms of modesty was described as "likely of me". This means that it is likely that the respondents recognize the value of their own privacy and respect that of others (Medina, et.al, 2017).

\section{Table 5. The Academic Personnel's Personality Type: Optimism}

\begin{tabular}{|l|c|c|c|}
\hline \multicolumn{1}{|c|}{ Indicators } & $\begin{array}{c}\text { Weighted } \\
\text { Mean }\end{array}$ & $\begin{array}{c}\text { Verbal } \\
\text { Interpretation }\end{array}$ & Rank \\
\hline \multicolumn{1}{|c|}{ I see myself as positive thinker. } & 4.30 & Likely of me & 10 \\
\hline I see myself in 10 years as a successful person. & 4.45 & Likely of me & 4.5 \\
\hline I expect good things than bad things to happen. & 4.23 & Likely of me & 13.5 \\
\hline I see myself as a person who will never give up. & 4.55 & Most likely of me & 1 \\
\hline I trust myself in everything I do. & 4.21 & Likely of me & 16 \\
\hline I see opportunity in every difficulty. & 4.11 & Likely of me & 21 \\
\hline I see positivity in every situation. & 4.38 & Likely of me & 7 \\
\hline I am grateful even in my smallest achievements. & 4.45 & Likely of me & 4.5 \\
\hline I consider compliments as confidence booster. & 4.23 & Likely of me & 13.5 \\
\hline I believe that I am better than other people. & 3.02 & Less likely of me & 25 \\
\hline I see failure as start of something new. & 3.64 & Likely of me & 24 \\
\hline I see myself as willing to accept help. & 4.15 & Likely of me & 19.5 \\
\hline I am willing to learn from other people. & 4.47 & Likely of me & 3 \\
\hline I spread positivity with confidence. & 4.30 & Likely of me & 10 \\
\hline I see goodness in everything. & 4.23 & Likely of me & 13.5 \\
\hline I accept criticisms about my personality. & 4.17 & Likely of me & 18 \\
\hline I allow people to judge me and then prove them wrong. & 4.15 & Likely of me & 19.5 \\
\hline I always have rooms for improvements. & 4.51 & Most likely of me & 2 \\
\hline I see myself as a better person compared before. & 4.36 & Likely of me & 8 \\
\hline I always see only the positive out of everything. & 4.00 & Likely of me & 23 \\
\hline I look for possible ways to solve my problems. & 4.40 & Likely of me & 6 \\
\hline I always have faith in whatever happens. & 4.30 & Likely of me & 10 \\
\hline I have faith in everything. & 4.23 & Likely of me & 13.5 \\
\hline I believe that I create a happy environment by smiling. & 4.19 & Likely of me & 17 \\
\hline I believe that I can forgive others easily. & 4.04 & Likely of me & 22 \\
\hline A verage Weighted Mean & 4.20 & Likely of me & \\
\hline
\end{tabular}

It could be described with the average weighted mean of 4.20 that the respondents were likely to manifest optimism which means that they were confident, in terms of their reasoning, their own abilities, and that they appreciate the help they get from themselves or from others (Medina, et.al, 2017).

Table 6. The Academic Personnel's Personality Type: Respect for Others

\begin{tabular}{|c|c|c|c|}
\hline Indicators & $\begin{array}{l}\text { Weighted } \\
\text { Mean }\end{array}$ & $\begin{array}{c}\text { Verbal } \\
\text { Interpretation }\end{array}$ & Rank \\
\hline I speak to everyone in the same way. & 3.94 & Likely of me & 24 \\
\hline I treat people merely as they are. & 4.02 & Likely of me & 22.5 \\
\hline I listen to what another has to say. & 4.36 & Likely of me & 16.5 \\
\hline I treat people the way they want to be treated. & 4.23 & Likely of me & 20 \\
\hline I talk to people the way I want to be talked to. & 4.32 & Likely of me & 19 \\
\hline I never judge someone by the way he looks. & 3.40 & Less likely of me & 25 \\
\hline I respect the opinions of others. & 4.68 & Most likely of me & 1 \\
\hline I never underestimate a person's dignity. & 4.62 & Most likely of me & 5 \\
\hline I treat others as I want them to treat me. & 4.34 & Likely of me & 18 \\
\hline $\begin{array}{l}\text { I always offer respect to others and never expect anything in } \\
\text { return. }\end{array}$ & 4.64 & Most likely of me & 3 \\
\hline I offer something that I have. & 4.21 & Likely of me & 21 \\
\hline I thank people for their assistance. & 4.62 & Most likely of me & 5 \\
\hline I thank people for their support. & 4.53 & Most likely of me & 10 \\
\hline I say "thanks" or "thank you" when someone helps me. & 4.66 & Most likely of me & 2 \\
\hline
\end{tabular}




\begin{tabular}{|l|c|c|c|}
\hline I recognize the achievement of others. & 4.55 & Most likely of me & 8 \\
\hline I recognize people who exert extra effort. & 4.36 & Likely of me & 16.5 \\
\hline I learn to recognize when other people achieve something. & 4.53 & Most likely of me & 10 \\
\hline I am sincere. & 4.62 & Most likely of me & 5 \\
\hline I offer my assistance to others. & 4.45 & Likely of me & 13.5 \\
\hline I practice active listening. & 4.40 & Likely of me & 15 \\
\hline I watch and stay quiet when someone else is talking. & 4.53 & Most likely of me & 10 \\
\hline I learn to empathize with other people. & 4.45 & Likely of me & 13.5 \\
\hline I respect the perspective of the other people. & 4.47 & Likely of me & 12 \\
\hline I don't judge people before I get to know them. & 4.02 & Likely of me & 22.5 \\
\hline I say "po" and "opo" to the elders. & 4.60 & Most likely of me & 7 \\
\hline Average Weighted Mean & 4.38 & \multicolumn{2}{|c|}{ Likely of me } \\
\hline
\end{tabular}

The average weighted mean of 4.38 interpreted as "likely of me" mean that the respondents were likely to have respect for others, acts or refrains from acting so as not to harm them, instead, acts in accordance to benefit oneself and others taking into consideration people's rights, status and circumstances. (Medina, et.al, 2017).

Table 7. Composite Table for Academic Personnel's Personality Type based from Perpetualites Campus-based Personality Profile

\begin{tabular}{|cl|c|l|c|}
\hline \multicolumn{1}{|c|}{ Indicators } & $\begin{array}{c}\text { Weighted } \\
\text { Mean }\end{array}$ & $\begin{array}{c}\text { Verbal } \\
\text { Interpretation }\end{array}$ & Rank \\
\hline 1. & Abasement & 4.08 & Likely of me & 5 \\
\hline 2. & Achievement & 4.31 & Likely of me & 3 \\
\hline 3. & Deference & 4.38 & Likely of me & 1.5 \\
\hline 4. & Modesty & 3.88 & Likely of me & 6 \\
\hline 5. & Optimism & 4.20 & Likely of me & 4 \\
\hline 6. & Respect for Others & 4.38 & Likely of me & 1.5 \\
\hline
\end{tabular}

All the personality traits were rated by the respondents as "likely of me" with 4.38 as the highest mean both for the traits deference and respect for others. This was supported by the study of Medina, Rosas andVitug (2017) which highlighted that the Perpetualites possess dominant common traits which are abasement, deference, and achievement as being described by Henry Murray as the psychogenic needs (Burger, 2013). It was also revealed that another three common traits manifested by the Perpetualites based on Building Blocks of Character Development are modesty, respect of others, and optimism (Perpetualite Community, 2015). Generally, we can describe the academic personnel of the UPHSL as employees who are cooperative and that they admire and willingly follow their superior, and that they were respective of people's rights and status, thus avoiding any circumstances where they could offend or hurt others (Oreste, 2012).

Table 8. The Academic Personnel's Level of Organizational Commitment

\begin{tabular}{|c|c|c|c|}
\hline Indicators & $\begin{array}{l}\text { Weighted } \\
\text { Mean }\end{array}$ & $\begin{array}{c}\text { Verbal } \\
\text { Interpretation }\end{array}$ & Rank \\
\hline $\begin{array}{l}\text { I tell my friends UPHSL is a good organization to work } \\
\text { for. }\end{array}$ & 3.32 & Agree/High & 12 \\
\hline I express loyalty to UPHSL. & 3.66 & $\begin{array}{l}\text { Strongly Agree/Very } \\
\text { High } \\
\end{array}$ & 2.5 \\
\hline $\begin{array}{l}\text { I would accept almost any type of job assignment in order to } \\
\text { keep working for UPHSL. }\end{array}$ & 3.02 & Agree/High & 23 \\
\hline I find that my values and UPHSL values are very similar. & 3.19 & Agree/High & 19 \\
\hline $\begin{array}{l}\text { I understand how my job contributes to the UPHSL goals } \\
\text { and objectives. }\end{array}$ & 3.74 & $\begin{array}{l}\text { Strongly Agree/Very } \\
\text { High }\end{array}$ & 1 \\
\hline I am proud to tell others that I am part of UPHSL family. & 3.66 & $\begin{array}{l}\text { Strongly Agree/Very } \\
\text { High }\end{array}$ & 2.5 \\
\hline $\begin{array}{l}\text { I am willing to put in a great deal of extra effort to help } \\
\text { UPHSL be more successful. }\end{array}$ & 3.60 & $\begin{array}{l}\text { Strongly Agree/Very } \\
\text { High }\end{array}$ & 4 \\
\hline $\begin{array}{l}\text { I would not consider working for a different organization } \\
\text { even if the work is similar. }\end{array}$ & 3.15 & Agree/High & 20.5 \\
\hline
\end{tabular}




\begin{tabular}{|c|c|c|c|}
\hline $\begin{array}{l}\text { I am extremely glad that I chose to work here rather than } \\
\text { one of the other jobs I was considering at the time I joined. }\end{array}$ & 3.30 & Agree/High & 14 \\
\hline $\begin{array}{l}\text { There.is much to be gained by staying with this } \\
\text { organization indefinitely. }\end{array}$ & 3.23 & Agree/High & 18 \\
\hline $\begin{array}{l}\text { I often find it logical to agree with UPHSL policies on } \\
\text { important matters relating to its employees. }\end{array}$ & 3.36 & Agree/High & 8.5 \\
\hline I really care about the fate of this organization. & 3.34 & Agree/High & 10.5 \\
\hline $\begin{array}{l}\text { For me UPHSL is the best of all possible organizations } \\
\text { for which to work. }\end{array}$ & 2.94 & Agree/High & 25 \\
\hline $\begin{array}{l}\text { Deciding to work for UPHSL was never a mistake on my } \\
\text { part. }\end{array}$ & 3.28 & Agree/High & 16 \\
\hline I speak highly of UPHSL to my friends. & 3.13 & Agree/High & 22 \\
\hline I think UPHSL is a good place to work in. & 3.15 & Agree/High & 20.5 \\
\hline UPHSL inspires the best job performance from me. & 3.02 & Agree/High & 24 \\
\hline I am proud to be part of my section/department/service. & 3.36 & Agree/High & 8.5 \\
\hline $\begin{array}{l}\text { I understand how my work contributes to UPHSL goals } \\
\text { and objectives. }\end{array}$ & 3.55 & $\begin{array}{l}\text { Strongly Agree/Very } \\
\text { High }\end{array}$ & 6 \\
\hline I would recommend UPHSL as a good place to work. & 3.26 & Agree/High & 17 \\
\hline $\begin{array}{l}\text { UPHSL has improved as a place to work over the past } \\
\text { two years. }\end{array}$ & 3.57 & $\begin{array}{l}\text { Strongly Agree/Very } \\
\text { High }\end{array}$ & 5 \\
\hline I work in a well-managed organization. & 3.34 & Agree/High & 10.5 \\
\hline Morale in UPHSL is good. & 3.30 & Agree/High & 14 \\
\hline UPHSL has one of the best reputations in the industry. & 3.30 & Agree/High & 14 \\
\hline I am proud of the quality of graduates UPHSL produce. & 3.43 & Agree/High & 7 \\
\hline Average Weighted Mean & 3.33 & Agree/High & \\
\hline
\end{tabular}

The average weighted mean of 3.33, verbally interpreted as high level of organizational commitment. The items were concentrated on the employees' reaction to UPHSL as their employer and this result means that the respondents identify themselves in UPHSL, expressing strong belief and acceptance of its values and principles. Likewise, the academic personnel is ready to exert considerable effort on behalf of the organization and expressed strong desire to remain as part of the UPHSL community (Quiambao \&Nuqui, 2017).

Table 9. The Academic Personnel's Extent of Collaborative Alliance

\begin{tabular}{|c|c|c|c|}
\hline Indicators & Mean & Verbal Interpretation & Rank \\
\hline \multicolumn{4}{|l|}{ Marketing and Promotion } \\
\hline $\begin{array}{l}\text { I actively join the Marketing Department in recruiting students by } \\
\text { participating in school to school campaign. }\end{array}$ & 2.70 & $\begin{array}{c}\text { Agree/ } \\
\text { to a moderate extent }\end{array}$ & 2 \\
\hline $\begin{array}{l}\text { I exhaust all possible means to promote the program offerings of } \\
\text { UPHSL as a means to collaborate with the Marketing Department. }\end{array}$ & 2.87 & $\begin{array}{c}\text { Agree/ } \\
\text { to a moderate extent }\end{array}$ & 1 \\
\hline $\begin{array}{l}\text { 3. I use my personal social media accounts (Facebook, Instagram, } \\
\text { Tweeter, etc) to promote programs, activities, board ratings, etc. } \\
\text { of UPHSL as my way of helping the Marketing the Department. }\end{array}$ & 2.49 & $\begin{array}{l}\text { Disagree/ } \\
\text { to a less extent }\end{array}$ & 5 \\
\hline $\begin{array}{l}\text { 4.To collaborate with the Marketing Department, during semestral } \\
\text { breaks, I spend some time in texting and calling old students who } \\
\text { have not yet enrolled, encouraging them to enroll. }\end{array}$ & 2.62 & $\begin{array}{l}\text { Agree/ } \\
\text { to a moderate extent }\end{array}$ & 4 \\
\hline $\begin{array}{l}\text { 5.I talk to UPHSL alumni (personal and/or on-line) and update } \\
\text { them about the recent developments in school then later on ask } \\
\text { them for some referrals on prospective enrollees. }\end{array}$ & 2.64 & $\begin{array}{c}\text { Agree/ } \\
\text { to a moderate extent }\end{array}$ & 3 \\
\hline Average Weighted Mean & 2.66 & to a moderate extent & 4 \\
\hline \multicolumn{4}{|l|}{ Research Involvement } \\
\hline $\begin{array}{l}\text { I actively attend seminars and training organized by the Research } \\
\text { and Development Center to enhance my skills in conducting } \\
\text { research. }\end{array}$ & 3.36 & $\begin{array}{c}\text { Agree/ } \\
\text { to a moderate extent }\end{array}$ & 1 \\
\hline $\begin{array}{l}\text { I find time to partner with seasoned researchers to } \\
\text { collaborate with their research endeavor. }\end{array}$ & 3.02 & $\begin{array}{c}\text { Agree/ } \\
\text { to a moderate extent }\end{array}$ & 3 \\
\hline I regularly conduct relevant research not only to collaborate with & 2.85 & Agree/ & \\
\hline
\end{tabular}




\begin{tabular}{|c|c|c|c|}
\hline $\begin{array}{l}\text { the Research and Development Center buy also to improve } \\
\text { knowledge and learning. }\end{array}$ & & to a moderate extent & 5 \\
\hline $\begin{array}{l}\text { 4. I find time to help fellow Perpetualites in their research } \\
\text { endeavors whenever necessary. }\end{array}$ & 2.98 & $\begin{array}{c}\text { Agree/ } \\
\text { to a moderate extent }\end{array}$ & 4 \\
\hline $\begin{array}{l}\text { 5. I participate (or willing to participate) in presenting my research } \\
\text { paper in institutional and/or local fora. }\end{array}$ & 3.23 & $\begin{array}{c}\text { Agree/ } \\
\text { to a moderate extent }\end{array}$ & 2 \\
\hline Average Weighted Mean & 3.09 & to a moderate extent & 3 \\
\hline \multicolumn{4}{|l|}{ Community Outreach Program Involvement } \\
\hline $\begin{array}{l}\text { 1.I actively engage in institutional outreach programs spearheaded } \\
\text { by the Community Extension Office. }\end{array}$ & 3.11 & $\begin{array}{c}\text { Agree/ } \\
\text { to a moderate extent }\end{array}$ & 4 \\
\hline $\begin{array}{l}\text { I coordinate with the Community Extension Office departmental } \\
\text { outreach programs my unit has conceptualized. }\end{array}$ & 2.94 & $\begin{array}{c}\text { Agree/ } \\
\text { to a moderate extent }\end{array}$ & 5 \\
\hline $\begin{array}{l}\text { 3.As part of my unit's collaboration with the Community } \\
\text { Extension Office, I exhaust all possible means for my department } \\
\text { to give back to the community, be it material or service assistance. }\end{array}$ & 3.13 & $\begin{array}{c}\text { Agree/ } \\
\text { to a moderate extent }\end{array}$ & 3 \\
\hline $\begin{array}{l}\text { 4.I am willing to participate in the sementral and/or annual } \\
\text { planning for a wider implementation of institutional community } \\
\text { outreach programs. }\end{array}$ & 3.15 & $\begin{array}{c}\text { Agree/ } \\
\text { to a moderate extent }\end{array}$ & 2 \\
\hline $\begin{array}{l}\text { 5.I am more than willing to volunteer my personal resources, } \\
\text { talent and capabilities for the benefit of the UPHSL adopted } \\
\text { barangay(s). }\end{array}$ & 3.23 & $\begin{array}{c}\text { Agree/ } \\
\text { to a moderate extent }\end{array}$ & 1 \\
\hline Average Weighted Mean & 3.11 & to a moderate extent & 2 \\
\hline \multicolumn{4}{|l|}{ Customer Satisfaction } \\
\hline $\begin{array}{l}\text { To make sure I give quality service to students, I regularly consult } \\
\text { other departments and student support services for a more } \\
\text { coordinated implementation of student programs. }\end{array}$ & 3.40 & $\begin{array}{c}\text { Agree/ } \\
\text { to a moderate extent }\end{array}$ & 4 \\
\hline $\begin{array}{l}\text { 2. Whenever necessary, I professionally discuss some students } \\
\text { feedback to the concerned co-employee for the improvement of } \\
\text { services rendered. }\end{array}$ & 3.49 & $\begin{array}{c}\text { Agree/ } \\
\text { to a moderate extent }\end{array}$ & 2 \\
\hline $\begin{array}{l}\text { 3. In cases where students express sentiments against specific } \\
\text { office/department, I calmly defend the concerned office by } \\
\text { explaining possible reasons for such shortcomings. }\end{array}$ & 3.34 & $\begin{array}{c}\text { Agree/ } \\
\text { to a moderate extent }\end{array}$ & 5 \\
\hline $\begin{array}{l}\text { 4. I actively participate in institutional capacity building trainings } \\
\text { for a more unified and coordinated student services. }\end{array}$ & 3.66 & $\begin{array}{l}\text { Strongly agree/ } \\
\text { to a great extent }\end{array}$ & 1 \\
\hline $\begin{array}{l}\text { 5.If necessary, I am willing to extend assistance to other offices by } \\
\text { rendering considerable duty hours in instances such as enrollment } \\
\text { period, signing of clearances, graduation requirements and the } \\
\text { like. }\end{array}$ & 3.47 & $\begin{array}{c}\text { Agree/ } \\
\text { to a moderate extent }\end{array}$ & 3 \\
\hline Average Weighted Mean & 3.47 & to a moderate extent & 1 \\
\hline Overall Average Weighted Mean & 3.08 & to a moderate ext & \\
\hline
\end{tabular}

First in ranking is customer satisfaction with an average weighted mean of 3.47 verbally interpreted as to a moderate extent of collaborative alliance in terms of customer satisfaction with"I actively participate in institutional capacity building trainings for a more unified and coordinated student services" as the indicator with the highest mean (3.66) interpreted as "to a great extent" of collaborative alliance. Second in ranking is collaborative alliance in terms of community outreach involvement with an average weighted mean of 3.11 also interpreted as "to a moderate extent" of collaborative alliance. The highest in ranking for community outreach involvement is the item "I am more than willing to volunteer my personal resources, talent and capabilities for the benefit of the UPHSL adopted barangay(s)." with a mean of 3.23 verbally interpreted as to a moderate extent of collaborative alliance. Third in the ranking of collaborative alliance is research involvement with an average weighted mean of 3.09 still verbally interpreted as to a moderate extent of collaborative alliance with the indicator "I actively attend seminars and training organized by the Research and Development Center to enhance my skills in conducting research" that obtained the highest mean of 3.36 verbally interpreted as to a moderate extent. Last in ranking for the collaborative alliance is marketing and promotion having obtained an average weighted mean of 2.66 verbally interpreted as to a moderate extent of collaborative alliance. 
For marketing and promotion, the highest in ranking is the indicator "I exhaust all possible means to promote the program offerings of UPHSL as a means to collaborate with the Marketing Department" with a mean of 2.87 interpreted as to a moderate extent of collaborative alliance. The over-all weighted average mean of 3.08 revealed that the academic personnel has a moderate extent of involvement in institutional marketing and promotion, research involvement, community outreach program involvement and customer satisfaction.

Wohlstetter, Malloy,Hentschke and Smith (2004) highlighted the advantage of collaborative alliance in educational organizations. Such alliance accordingly, can address problemsand needs that are beyond the capability of individual organizations in asingle sector. This will result to enhanced capacity and improve educational services.

The fact that marketing and promotion was rated last among respondents could be attributed, according to KalimullinandDobrotvorskaya (2016), to reason such that marketing involves several factors such as choice of a university and an academic program by enrollees, as well as socio-psychological characteristics of the latter, while systematic research of this problem has not been done by now.

Table 10. Relationship between the Respondents' Personality Type and their Level of Organizational Commitment

\begin{tabular}{|l|c|c|c|}
\hline \multirow{2}{*}{ Personality Type } & \multicolumn{3}{|c|}{ Level of Organizational Commitment } \\
\cline { 2 - 4 } & Pearson $\mathrm{r}$ & $\mathrm{p}$-value & Interpretation \\
\hline Abasement & .378 & $.009^{* *}$ & Significant \\
\hline Achievement & .409 & $.004^{* *}$ & Significant \\
\hline Deference & .555 & $.000^{* *}$ & Significant \\
\hline Modesty & .087 & .560 & Not significant \\
\hline Optimism & .132 & .376 & Not significant \\
\hline Respect for Others & .349 & $.016^{*}$ & Significant \\
\hline Overall & .347 & $.017^{*}$ & Significant \\
\hline **Significant @0.01 & \multicolumn{4}{|l}{} \\
*Significant @0.05 & \multicolumn{4}{|l}{} \\
\hline
\end{tabular}

Table 10 presents the relationship between the respondents' personality type and their level of organizational commitment. Although it showed that the respondents' personality traits modesty (pvalue=.560) and optimism (pvalue =.376) were not significantly related to their level of organizational commitment, it was well noted that their personality traits abasement (pvalue=.009), achievement (pvalue $=.004$ ), deference (pvalue $=.000$ ) were all were all significant at 0.01 level and respect for others (pvalue=.016) at 0.05 level. Overall, their personality type is significantly related with their level of organizational commitment with its computed value of .017 which is lower than 0.05 level. This means that the more the respondents manifest traits such as abasement, achievement, deference, and respect for others, the higher is their level of organizational commitment to UPHSL.

This result is supported by the study of Prayitno1, Suwandi andHamidah (2016) who analyzed how the Big 5 personality traits of workers in manufacturing industries directly affect their organizational commitment. Result of this study showed that their personality traits openness, conscientiousness, extroversion, agreeableness and neuroticism is correlated with their organizational commitment.

Another study conducted by Lo, Lin and Tung-Hsing (2014) showed that there is consistently positive relation among personal traits, career development, and organizational commitment. First, among the personal traits indicator, agreeableness can explain the largest part of individual career planning. Secondly, openness to experiences can explain the largest part of organizational career management. In addition, career planning, career counselling, agreeableness, and career tactics attain significant level in explaining the organizational commitment.

Table 11. Relationship between the Respondents' Personality Type and their Extent of Collaborative Alliance

\begin{tabular}{|c|c|c|c|c|c|}
\hline \multirow[b]{2}{*}{ Personality Type } & \multicolumn{5}{|c|}{ Extent of Collaborative Alliance } \\
\hline & $\begin{array}{l}\text { Marketing } \\
\text { and } \\
\text { Promotion }\end{array}$ & $\begin{array}{l}\text { Research } \\
\text { Involvement }\end{array}$ & $\begin{array}{c}\text { COP } \\
\text { Involvement }\end{array}$ & $\begin{array}{l}\text { Customer } \\
\text { Satisfaction }\end{array}$ & Overall \\
\hline Abasement & $\begin{array}{c}\mathrm{r}=-0.053 \\
\mathrm{p}=0.724 \\
\mathrm{NS}\end{array}$ & $\begin{array}{c}\mathrm{r}=-0.094 \\
\mathrm{p}=0.529 \\
\mathrm{NS}\end{array}$ & $\begin{array}{c}\mathrm{r}=-0.061 \\
\mathrm{p}=0.686 \\
\mathrm{NS}\end{array}$ & $\begin{array}{c}\mathrm{r}=0.646 \\
\mathrm{p}=0.000^{* *}\end{array}$ & $\begin{array}{c}\mathrm{r}=0.646 \\
\mathrm{p}=0.000^{* *}\end{array}$ \\
\hline Achievement & $\begin{array}{c}\mathrm{r}=-0.071 \\
\mathrm{p}=0.636 \\
\mathrm{NS}\end{array}$ & $\begin{array}{c}\mathrm{r}=0.134 \\
\mathrm{p}=0.369 \\
\mathrm{NS}\end{array}$ & $\begin{array}{c}\mathrm{r}=0.163 \\
\mathrm{p}=0.275 \\
\mathrm{NS}\end{array}$ & $\begin{array}{c}\mathrm{r}=0.735 \\
\mathrm{p}=0.00 * *\end{array}$ & $\begin{array}{c}\mathrm{r}=0.735 \\
\mathrm{p}=0.000 * *\end{array}$ \\
\hline Deference & $r=-0.031$ & $r=-0.007$ & $r=0.065$ & $r=0.751$ & $r=0.751$ \\
\hline
\end{tabular}




\begin{tabular}{|l|c|c|c|c|c|}
\hline & $\mathrm{p}=0.838$ & $\mathrm{p}=0.965$ & $\mathrm{p}=0.662$ & $\mathrm{p}=0.000^{* *}$ & $\mathrm{p}=0.000^{* *}$ \\
& $\mathrm{NS}$ & $\mathrm{NS}$ & $\mathrm{NS}$ & & \\
\hline Modesty & $\mathrm{r}=0.067$ & $\mathrm{r}=0.077$ & $\mathrm{r}=-0.003$ & $\mathrm{r}=0.499$ & $\mathrm{r}=0.499$ \\
& $\mathrm{p}=0.654$ & $\mathrm{p}=0.606$ & $\mathrm{p}=0.982$ & $\mathrm{p}=0.000^{* *}$ & $\mathrm{p}=0.000^{* *}$ \\
& $\mathrm{NS}$ & $\mathrm{NS}$ & $\mathrm{NS}$ & & \\
\hline Optimism & $\mathrm{r}=-0.149$ & $\mathrm{r}=0.156$ & $\mathrm{r}=0.167$ & $\mathrm{r}=0.546$ & $\mathrm{r}=0.546$ \\
& $\mathrm{p}=0.318$ & $\mathrm{p}=0.295$ & $\mathrm{p}=0.262$ & $\mathrm{p}=0.000^{* *}$ & $\mathrm{p}=0.000^{* *}$ \\
& $\mathrm{NS}$ & $\mathrm{NS}$ & $\mathrm{NS}$ & & \\
\hline Respect for Others & $\mathrm{r}=-0.205$ & $\mathrm{r}=0.113$ & $\mathrm{r}=0.149$ & $\mathrm{r}=0.537$ & $\mathrm{r}=0.537$ \\
& $\mathrm{p}=0.166$ & $\mathrm{p}=0.449$ & $\mathrm{p}=0.318$ & $\mathrm{p}=0.000^{* *}$ & $\mathrm{p}=0.000^{* *}$ \\
& $\mathrm{NS}$ & $\mathrm{NS}$ & $\mathrm{NS}$ & & \\
\hline Overall & $\mathrm{r}=-0.080$ & $\mathrm{r}=0.076$ & $\mathrm{r}=0.093$ & $\mathrm{r}=0.691$ & $\mathrm{r}=0.691$ \\
& $\mathrm{p}=0.591$ & $\mathrm{p}=0.611$ & $\mathrm{p}=0.534$ & $\mathrm{p}=0.000^{* *}$ & $\mathrm{p}=0.000^{* *}$ \\
& $\mathrm{NS}$ & $\mathrm{NS}$ & $\mathrm{NS}$ & & \\
\hline **Significant @0.01 & \multicolumn{5}{|c|}{} \\
*Significant @0.05 & \multicolumn{5}{|l|}{} \\
\hline
\end{tabular}

The respondents' personality traits abasement, achievement, deference, modesty, optimism, and respect of others is not significantly related to their collaborative alliance in terms of institutional marketing and promotion, research involvement and community outreach program involvement. This means that the respondents' willingness to be involved in those institutional services has nothing to do with their such personality traits mentioned. On the other hand, significant relationships were being noted with the respondents' personality traits abasement $(p=0.000)$, achievement $(\mathrm{p}=0.00)$, deference $(\mathrm{p}=0.000)$, modesty $(\mathrm{p}=0.000)$, optimism $(\mathrm{p}=0.000)$, and respect for others $(\mathrm{p}=$ 0.000 ) and their extent of collaborative alliance in terms of institutional customer satisfaction at 0.01 level of significance. Their personality traits based from Perpetualites' Campus based Personality Type were also significantly related to their overall extent of collaborative alliance $(p=0.000)$ at 0.01 level of significance. This means that the more the respondents manifest traits such as abasement, achievement, deference, modesty, optimism, respect for others, the greater is their extent of collaborative alliance especially in terms of giving quality service to satisfy their stakeholders.

In a study by Blickle, Wendel and Ferris (2010) which involved job performance of automobile sales agent, it was found out the respondents' personality type is directly correlated to their sales performance. Specifically, they investigated whether interactions of the five-factor model constructs of extraversion and openness to experience with political skill predict sales performance. For individuals high on political skill, higher levels of extraversion were associated with higher levels of sales. For individuals who are low on political skill, higher levels of extraversion were associated with lower levels of sales.Likewise, a study by Robinson (2010) found out that service quality was positively correlated to providers with extraverted personalities. These findings were consistent with prior and current research in the field. This ultimately impacts the quality of the service experience and how clients perceive service quality.

Table 12. Relationship between the Respondents' Level of Organizational Commitment and their Extent of Collaborative Alliance

\begin{tabular}{|c|c|c|c|c|c|}
\hline & $\begin{array}{l}\text { Marketing } \\
\text { and } \\
\text { Promotion }\end{array}$ & $\begin{array}{l}\text { Research } \\
\text { Involvement }\end{array}$ & $\begin{array}{c}\text { COP } \\
\text { Involvement }\end{array}$ & $\begin{array}{l}\text { Customer } \\
\text { Satisfaction }\end{array}$ & Overall \\
\hline $\begin{array}{l}\text { Respondents' } \\
\text { Level of } \\
\text { Organizational } \\
\text { Commitment and } \\
\text { their Extent of } \\
\text { Collaborative } \\
\text { Alliance }\end{array}$ & $\begin{array}{c}\mathrm{r}=0.367 \\
\mathrm{p}=0.011^{*}\end{array}$ & $\begin{array}{c}\mathrm{r}=0.086 \\
\mathrm{p}=0.564 \\
\mathrm{NS}\end{array}$ & $\begin{array}{c}\mathrm{r}=0.334 \\
\mathrm{p}=0.022^{*}\end{array}$ & $\begin{array}{c}\mathrm{r}=0.770 \\
\mathrm{p}=0.000^{* *}\end{array}$ & $\begin{array}{c}\mathrm{r}=0.770 \\
\mathrm{p}=0.000^{* *}\end{array}$ \\
\hline \multicolumn{5}{|c|}{$\begin{array}{l}\text { **Significant @ } 0.01 \\
* \text { Significant @ } 0.05\end{array}$} & \\
\hline
\end{tabular}

Only the respondents' extent of collaborative alliance in institutional research involvement is not significantly related to their level of organizational commitment having obtained a pvalue of 0.564 which is higher than 0.05 level of significance. 
But, data shows that the respondents' level of organizational commitment is significantly related to their collaborative alliance in terms of institutional marketing and promotion $(\mathrm{p}=0.011)$, community outreach program involvement $(\mathrm{p}=$ 0.022 ) both significant at 0.05 level and institutional customer satisfaction $(\mathrm{p}=0.000)$ significant at 0.01 level. It further shows that the overall extent of collaborative alliance is significantly related with the respondents' level of organizational commitment with a pvalue of 0.000 which is lower than 0.01 level of significance. This means that the higher the level of the academic personnel's organizational commitment, the greater is their greater is their involvement in institutional marketing and promotion, community outreach program involvement and customer satisfaction.

Matthew (2013) studies the factors Influencing faculty participation in internationalization at the University of Minnesota's Schools and findings revealed that the faculty members' participation in institutional projects depend widely on different factors, and this these include the college or department where they belong, their gender as well as their appointment types or security of tenure.A study by Ting (2010) few school or educational studies have simultaneously explored both internal marketing and organizational commitment. But then the results showed that internal marketing has a direct impact on organizational commitment. Moreover, job involvement and job satisfaction play partial mediating roles in the relationship between internal marketing and organizational commitment.

\section{Conclusion}

All the personality traits were rated by the respondents as "likely of me" with 4.38 as the highest mean both for the traits deference and respect for others. We can describe the academic personnel of the UPHSL as employees who are cooperative and that they admire and willingly follow their superior, and that they were respective of people's rights and status, thus avoiding any circumstances where they could offend or hurt others. The average weighted mean of 3.33, showed a high level of organizational commitment. The items were concentrated on the employees' reaction to UPHSL as their employer and this result means that the respondents identify themselves in UPHSL, expressing strong belief and acceptance of its values and principles. Likewise, the academic personnel are ready to exert considerable effort on behalf of the organization and expressed strong desire to remain as part of the UPHSL community. For collaborative alliance, the mean of 3.08 revealed academic personnel's moderate extent of involvement in institutional marketing and promotion, research involvement, community outreach program involvement and customer satisfaction; themore they manifest abasement, achievement, deference, and respect for others, the higher is their level of organizational commitment and the more they manifest the Perpetualitestraits the greater is their extent of collaborative alliance especially in terms of giving quality service to satisfy their stakeholders; and that the higher the level of the academic personnel's organizational commitment, the greater is their greater is their involvement in institutional marketing and promotion, community outreach program involvement and customer satisfaction.

\section{Future Directions}

Although the academic personnel recorded a high level of organizational commitment, department heads along with the employees can observe other organizations and how they keep committed to their institution. Along with this, frequent communication with and among heads and subordinates are encouraged to keep the employees motivated and committed to the organization. Creating a rich employment environment is also highly encouraged. It was revealed that personal traits are important deterministic factors on academic personnel's organizational commitment. Therefore, the department heads need to further understand the employees' personal traits, provide proper motivation and counselling, and help them make a balanced plan between work and commitment and personal needs. The ones in charge of the marketing and promotion, research and community outreach program need to collaborate with the academic personnel to come up with effective ways to encourage cooperation and involvement. Encouraging inter-department feedbacks by making employees comfortable speaking about their comments and suggestions would also be helpful for a more evident collaboration. Further research on the research topic involving non-academic personnel of the UPHSL is also encouraged.

\section{References}

Armstrong, P. (2015). Effective school partnerships and collaboration for school improvement: a review of the evidence .Reference: DFE-RR466.ISBN: 978-1-78105-520-5. Retrieved: https://assets.publishing.service.gov.uk/government/uploads/system/uploads/attachment_data/file/467855/DFE -RR466_-_School_improvement_effective_school_partnerships.pdf

Beatty, M. (2013) Factors Influencing Faculty Participation in Internationalization at the University of Minnesota's Schools of Nursing and Public Health: A Case Study.ProQuest LLC, D.Ed. Dissertation, University of Minnesota. ERIC Number: ED561673. ISBN: 978-1-3034-2763-3,ISSN: N/A. Retrieved from https://eric.ed.gov/?q=organizational+commitment\%2binstitutional+involvement\&id=ED561673 
Blickle, G, Wendel, S\&Ferris, G. (2010) Political Skill as Moderator of Personality--Job Performance Relationships in Socioanalytic Theory: Test of the Getting Ahead Motive in Automobile Sales. Journal of Vocational Behavior, v76 n2 p326-335. Retrieved from https://eric.ed.gov/?id=EJ876607

Burger, J.M. (2013). Personality: An Introduction. Pasig City, Philippines. Cengage Learning Asia Pte Ltd (Philippine Branch).

Ekkanath, S (2017) How to Get Involved in Community Service in High School. College xpress. Retrieved from https://www.collegexpress.com/articles-and-advice/student-life/blog/how-get-involved-community-servicehigh-school/

Guay,R., Choi,D.,Oh,I.,Mitchell, M.,Mount,M.,Shin,K. (2016). Why people harm the organization and its members: Relationships among personality, organizational commitment, and workplace deviance. Human Performance. Jan-Mar2016, Vol. 29 Issue 1, p1-15. 15p. Retrieved https://www.tandfonline.com/doi/abs/10.1080/08959285.2015.1120305

Gul, H., (2002). OrgutselBaglilikYaklasimlarininMukayesesi and Degerlendirmesi, Ege University EgeAkademikBakisDergisi, 2 (1), 42.

Harris, M. (2010) Interdisciplinary Strategy and Collaboration:A Case Study of American Research Universities. Journal of Research Administration Volume XLI, Number 1, 2010. Retrieved from https://eric.ed.gov/?id=EJ886790

Huang, J. (2017) Building Research Collaboration Networks - An Interpersonal Perspective for Research Capacity Building. National Institute of Education, Singapore., Retrieved from https://files.eric.ed.gov/fulltext/EJ1157238.pdf

Judson, K \& Taylor, S. (2014). Moving from Marketization to Marketing of Higher Education: The Co-Creation of Value in Higher Education Higher Education Studies; Vol. 4, No. 1; ISSN 1925-4741 E-ISSN 1925-475X, Published by Canadian Center of Science and Education. Retrieved from: http://www.ccsenet.org/journal/index.php/hes/article/viewFile/30222/19418

Kalimullina, A.\&Dobrotvorskayaa, S. (2016) Higher Education Marketing Strategies Based on Factors Impacting the Enrollees' Choice of a University and an Academic Program. International Journal of Environmental \& Science Education, Vol. 11, No. 13, 6025-6040, Retrieved from http://www.ijese.net/makale/761

Kanter, R. (1968). Commitment and Social Organization: A Study of Commitment Mechanisms in Utopian Communities.American Sociological Review.Vol. 33, No. 4 (Aug., 1968), pp. 499-517 Retrieved from https://www.jstor.org/stable/2092438?seq=1\#page_scan_tab_contents

Kessler, E. (2013). Encyclopedia of Management Theory. Retrieved from http://dx.doi.org/10.4135/9781452276090

Lo, H. Lin, C, Lin \&Tu, P. (2014) The Mediator Effect of Career Development Between Personality Traits and Organizational Commitment: The Example of Sport Communication TechnologyTalents.TOJET: The Turkish Online Journal of Educational Technology - October 2014, volume 13 issue 4. Copyright () The Turkish Online Journal of Educational Technology. Retrieved from https://eric.ed.gov/?id=EJ1043182

Medina, J.G.,Rosas,R.M.\&Vitug, N.R. (2017)Perpetualites Personality Profile as Basis for Campus Based Personality Test. An Undergraduate ThesisPresented tothe Faculty of the College of Arts and SciencesUniversity of Perpetual Help System Laguna

Oliver, C. 1990. "Determinants of Interorganizational Relationships: Integration and FutureDirections." Academy of Management Review 15(2):241-65. Retrieved from http://www.dse.univr.it/documenti/OccorrenzaIns/matdid/matdid565790.pdf

Oplatka, IzharThe principal's role in marketing the School:Subjective interpretationsand personal influences Planning and Changingol. 38, No. 3\&4, 2007, pp. 208-221. Retrieved from https://files.eric.ed.gov/fulltext/EJ785722.pdf

Oreste, F. M. (2012). Is there a right to respect? Utilitas, Vol. 24 Issue 4, p. 502 -524 23p. DOI: 10.1017/ 10.1017/S0953820812000180

Pappas, S. (2013). Personality Traits \& Personality Types: What is Personality? Retrieved from http://www.livescience.com/41313-personality-traits.html

Perpetualite Community. (2015). I am a Perpetualite; Today's Builder, Tomorrow's Leader. Retrieved from http://perpetualdalta.edu.ph/community/i-am-a-perpetualite-todays-builder-tomorrows-leader/

Prayitno,H.Suwandi, T. Hamidah (2016) Organizational Commitment Mediating the Effects of Big FivePersonality Compliance to Occupational Safety Standard Operating Procedure. International Journal of Evaluation and Research in Education (IJERE) Vol.5, No.1, March 2016, pp. 14 21 ISSN: 2252-8822 Retrieved from https://files.eric.ed.gov/fulltext/EJ1094673.pdf 
Qiambao, D., Nuqui, A.(2017). Determinants of Organizational Commitment among the Faculty Members of Private Tertiary Institutions. Journal of Social Sciences \& Humanities Research, 3(1).1-14. Retrieved from http://advancejournals.org/2017/02/03/determinants-of-organizational-commitment-among-the-facultymembers-of-private-tertiary-institutions/

Robertson, P. J. 1998. “'Interorganizational Relationships: Key Issues for Integrated Services.'’Pp. 67-87 in Jacquelyn McCroskey and S. D. Einbinder, eds., Universities and Communities:Remaking Professional and Interprofessional Education for the Next Century. Westport,CT: Praeger Publishers.

Robinson, D. (2010) How Personality Traits and Job Satisfaction Influence Service Quality in Housing Agencies. ProQuest LLC, Ph.D. Dissertation, Capella University. ERIC Number: ED523029 Retrieved from: http://www.proquest.com/en-US/products/dissertations/individuals.shtml

Savas, A.C., Kosker, E., Demir, S., \&Utar, N. (2015). Teachers' perception on the Relationship between Change Leadership and Organizational Commitment. International Journal of Educational Methodology, 1(1), 9-18. doi: 10.12973/ijem.1.1.9

Sinan, Y. (2016) Analyzing the Relationship between Positive Psychological Capital andOrganizational Commitment of the TeachersReceived: April 28, 2016 Accepted: May 30, 2016 Online Published: July 26, 2016doi:10.5539/ies.v9n8p75 URL: http://dx.doi.org/10.5539/ies.v9n8p75

Ting, S. (2011). The Effect of Internal Marketing on Organizational Commitment: Job Involvement and Job Satisfaction as Mediators. Educational Administration Quarterly, v47 n2 p353-382 Apr 2011. Retrieved from https://eric.ed.gov/?id=EJ918006

Topaloglu, I.G. (2010). IsgorenlerinAdaletand EtikAlgilariAcisindanOrgutselGuvenileOrgutselBaglilikIliskisi(Unpublished Master Thesis).Ankara.

Upchurch,R.,Curtis,C.,Denver,S.(2009)Employee Motivation and Organizational Commitment: A Comparison of Tipped and Nontipped Restaurant Employees. International Journal of Hospitality \& Tourism Administration. DOI: $10.1080 / 15256480903088469$. Retrieved https://www.researchgate.net/publication/233085990_Employee_Motivation_and_Organizational_Commitme nt_A_Comparison_of_Tipped_and_Nontipped_Restaurant_Employees

Wohlstetter, P., Malloy, C., Hentschke, G. \&Smith, J. (2004) Improving Service Delivery in Education Through Collaboration: An Exploratory Study of the Role of Cross-Sectoral Alliances in the Development and Support of Charter Schoolsn SOCIAL SCIENCE QUARTERLY, Volume 85, Number 5, by the Southwestern Social Science Association

Yalcin, S. (2016). Analyzing the Relationship between Positive Psychological Capital and Organizational Commitment of the Teachers. Publication Type: Journal Articles; Reports - ResearchEducation Level: Elementary Education; Secondary Education Retrieved https://eric.ed.gov/?id=EJ1110217.

Zarah, L. (2018) 7 Reasons Why Research Is Important. Owlcation Academia. Retrieved from https://owlcation.com/academia/Why-Research-is-Important-Within-and-Beyond-the-Academe 